\title{
Bacteriological and Physical Analysis of Dug Wells in South Darfur (Tolus town) for Indication of Pollution by Enterococus E. faecalis and Coliform
}

\author{
Omar . $B^{1}$, Nada . $A^{2}$, Mohmad.$A^{3}$, Mustafa.$S^{4}$ \\ $1,2,3,4$ University of Nyala- Sudan
}

\begin{abstract}
The provision of safe and adequate water supply for the population has far reaching effects on health, productively and quality of life, as well as socio-economic development of the nation. The present study was undertaken to determine bacteriological quality of water sources in Tolus town, South Darfur state west Sudan. Water samples from fifteen randomly selected, unprotected dug wells were collected during rainy season (2001) and transferred and analyzed in Nyala veterinar research laboratory (N.V.R.L).Presumptive coliform test for determination of most probable number (MPN), followed by a physical confirmatory tests. Where, the investigation revealed that the number of bacteria is inversely proportional to Reynolds's number that is obeyed the laminar flow, which confirm the biological results. The investigation revealed that all the studied water sources were contaminated with faecal bacteria and have presumptive bacteria count above the permissible limits for sanitary water, recommended by (WHO, 2008).
\end{abstract}

Keyword: dug-wells, most probable number, faecal coliform Rynold's number

\section{Introduction}

Water is one of the most important elements for all forms of life. It is indispensible in the maintenance of life on the earth. Despite of this, human beings are continuing to pollute water sources resulting in provoking water related illnesses (WHO, 2008). According to world health organization (WHO) report in 2006 approximately three out of five persons in developing countries do not have access to safe drinking water, and only about one in four has any kind of sanitary facilities.

The quality of water and treatment of waterborne diseases are critical public health issues. Bacterial contamination of drinking water sources is the most common health risk (WHO 2008; Abera et.al 2011).

Total and faecal coliform have been used extensively for many years as an indicator of faecal contamination, to express microbiological quality of water as well as a Paramater to estimate diseases risk and the hygienic condition of water (Redy, 2009) .

In South Darfur state over $70 \%$ of communicable diseases are due to poor environmental health condition arising from unsafe and inadequate water-supply (Nada, 2003).

The provision of safe and adequate water supply for the population has far reaching effects on health, productivity and quality of life, as well as on secio-economic development of nations. Therefore the present study was designed to detect the coliform, Enterococcus faecalis to assess the quality of water sources and the extent of contamination of water in the studied area with intention to help the concerned bodies with the necessary information to take action, and to provide basic information for further study. The rotation of helicoidal flagella allows the motion of the E.coli at Reynolds number (Re ) and its caused by the drag anisotropy, (Lauga and Powers,2009).

$$
\int \frac{d N}{N}=\int r d t:\left.N(t)\right|_{t=0}=\ln N_{0}
$$

\section{Material and Methods}

Collection of samples:

Fifteen dug wells distributed along the valley (Wadi Bulbul) were randomly selected to study the possibility of their contamination with Enterococcus faecalis and coliform. $100 \mathrm{ml}$ of water samples from every well were collected, following WHO methods (1988). The water samples collected using sterile container tied by clean string, rubbers stoppers and transferred to Nyala veterinary research laboratory ( NVRL) in ice boxes to be analyzed using two methods.

$5 \mathrm{ml}$ of pure water added gradually, to different volume of water contaminated with bacteria. Then, based on the principle of the mechanical fluid, the relationship between MPN and Reynold's number ( $R e$ ) is found.

Total coliform Bacteria Presumptive test :

The most probable number (MPN) of total coliforms bacteria were determined by multiple tube fermentation technique (APHA, 2001) . A serial dilution from each water sample $\left(10^{-1}-10^{-5}\right)$ were inoculated in tubes containing double strength of $10 \mathrm{ml}$ Macconkey broth medium with inverted Durham tubes. All the cultures were incubated aerobically at $37-48 \mathrm{C}^{\circ}$ and examined for gas production.

\section{Confirmatory Tests}

Positive tubes for presumptive test were sub-cultured into Brilliant green bile (BGB) broth

and incubated at $37 \mathrm{C}^{\circ}$ for $24-48$ hours . Total coliform were calculated from (MPN) table as per $100 \mathrm{ml}$ of sample (APHA,2001).and (Deman, 1983). 


\section{International Journal of Science and Research (IJSR) \\ ISSN (Online): 2319-7064}

Index Copernicus Value (2013): 6.14 | Impact Factor (2015): 6.391

\section{Examination of Enterococci}

A glucose azide broth medium was used for the identification for Enterococci bacteria. All samples positive in the presumptive test, were sub-cultured and incubated at $44 \mathrm{C}^{\circ}$ for $24-48$ hours. A confirmatory test was carried out on bile asculin azide agar medium incubated at $44 \mathrm{C}^{0}-45$ $\mathrm{C}^{\mathrm{o}}$ for few hours

\section{Physical Analysis}

We encountered some interesting dimensionless groups when performing dimensional analysis of fluid mechanical problems. One problem Reynolds investigated experimentally is the transition of flow from the orderly kind that call the "laminar flow " to the more chaotic type of flow termed " turbulent flow " ( O.Reynolds, 1883 ).

We know that, bacteria growth rate is increased with proportion to its initial total number $N_{0}$ at time $t=0$, therefore, let $N(t)$ represents the number of bacteria at time $t$ . So, the increasing of growth rate of bacteria $\frac{d N}{d t}$ can be expressed as follow

$$
\frac{d N}{d t}=r N
$$

Where $r$ is the proportional constant

Therefore,

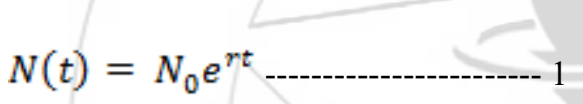

According to Fig (2) and Fig(3), we notice that,

$$
N(t)=\frac{1}{R_{e}}=\frac{\eta t}{\rho R L}
$$

Where $L$ is length of motion path of bacteria within time $t$ By differentiating the two sides of eq(2) with respect to time

$t$, we obtain

From eq(1), we obtain

$$
\frac{d N(t)}{d t}=\frac{\eta}{\rho R}
$$

$$
\frac{d N(t)}{d t}=N_{0} r e^{r t}
$$

By using eq(3) and eq(4), we obtain

$$
N(t)=N_{0} e^{\ln \frac{\eta}{\rho R N(t)} t}
$$

By using logarithm to the base 10 , we can obtain

$$
r=\frac{\log _{10} x_{2}-\log _{10} x_{1}}{t_{2}-t_{1}}
$$

Then we can obtain

Finally, we obtain

$$
r=\frac{10^{n_{2}}-10^{n_{1}}}{t_{2}-t_{1}}
$$

$$
N(t)=N_{0} e^{\ln \frac{10^{\Delta n}}{\Delta t}}
$$

Where $x_{1}$ is the number of cells at time $t_{1}, x_{2}$ is the number of cells at time $t_{2}, \mathrm{~N}_{0}$ is the number of bacteria per $\mathrm{mL}$ ( cell concentration ), $N(t)$ is the bacteria concentration at time $t, r$ is the instantaneous growth rate ( balance between cell division and cell death, per time unit .Such that $\eta$ is the viscosity of fluid, , Re is Reynold's number, $\mathrm{R}$ is the size of bacteria and $\rho$ is the density of fluid, and $\Delta n$ is the variance of cells Bacteria motility in water: $v_{s} \approx 30 \times 10^{-6} \mathrm{~m} / \mathrm{s}$ $R \approx 1 \times 10^{-6} \mathrm{~m}, \quad R_{\mathrm{e}} \approx 1 \times 10^{-5}$,
$\eta_{\text {water }} \approx 0.001 \mathrm{~Pa} . \mathrm{s}, \rho_{\text {water }}=\frac{1000 \mathrm{~kg}}{\mathrm{~m}^{\mathrm{s}}}$

\section{Results and Discussion}

Fifteen water samples were collected from dug-wells cited a long the bank of a seasonal valley (Wadi Bulbul) which represents the main water source of the town. The result of bacterial presumptive test revealed that all the studied water samples have bacterial count MPN above the permissible limits for drinking water. The MPN count of the samples range $17-3.5 \times 10^{6} / 100 \mathrm{ml}$ of water as shown in (Table 1)

Sample number 9 has the less MPN count for coliform bacterial test $(17 / 100 \mathrm{ml})$ whereas sample No, 5 has the highest MPN count $\left(3.5 \times 10^{6} / 100 \mathrm{ml}\right.$ of water $)$.

The presence of E.faecalis was confirmed almost in thirteen $(86.7 \%)$ studied wells. two wells $(13.3 \%)$ showed negative result for the presence of E.faecalis . (Table 2). Sample two showed the less MPN count for E. faecalis $\left(3.9 \times 10^{5}\right)$ and sample six show the highest MPN count $\left(160 \times 10^{5}\right)$. The result displayed in table 1 and 2 revealed that approximately all the studied water sources were contaminated with faecal coliform, which most likely was Ent feacalis .

The statistical test (T.test) for the most probable number count of coliform and E.faecalis and the comparison between them showed that there were significant differences within ( $\mathrm{P} \geq 0.05)$ as illustrated by Fig (1).

Also, the results in Fig(2), and Fig(3) showed that, the total $\mathrm{MPN} / \mathrm{ml}$ of the bacteria is inverse to Reynolds's Number ( Re ), this means high contamination of bacteria is occurred in water for range of $\operatorname{Re}\left(0.9 \times 10^{-3}-0.03 \times 10^{-6}\right)$, and for coliform counts. And for $\boldsymbol{E}$. faecalis counts, the range of $\mathrm{Re}$ is $\left(0.2 \times 10^{-6}-0.07 \times 10^{-9}\right)$.

The contamination of water sources obtained in this research could be attributed to the following facts, the main water sources in the studied area, are surface ground water found in the Wadi aquifer which make it very vulnerable to pollution. Dahiya and Kar,(1999), and Battu etal.,(2009), reported that surface water source in general, are not acceptable for drinking purpose as they are often loaded by various organic, inorganic and biological constituents.

The existence of the market place near the water sources, within a distance of less than $30 \mathrm{~m}$, which is below WHO recommendation for minimum distance that should exist between human activities and water sources, together with the extensive livestock turnover being held for most of the time in the town and pass the water sources in their daily journey, for the sought of pasture gives a continuous health hazard for the quality of water in the studied area, On top of the above mentioned reasons, the valley which represents 


\section{International Journal of Science and Research (IJSR) \\ ISSN (Online): 2319-7064 \\ Index Copernicus Value (2013): 6.14 | Impact Factor (2015): 6.391}

the main water source, dries during winter and summer, and its beds become casual latrines both for the residents and the market visitors

The findings of this research is in agreement with two studies (Nada, 2003) and (Amira, 2011) conducted in Nyala town South Darfur, Sudan for the investigation of drinking water quality. However, to our knowledge the information obtained in this study about faecal contamination of water sources in Tolus town is the first of its kind, and it revealed the hygienic conditions of water sources which consumed by the community. The Beer-Lambert law, as applied spectrophotmetric turbidity studies, correlates the concentration of the organismal growth in a solution that absorb the visible light (Sarah.Spence, 2011 )

Table 1: Results of total presumptive Coliform counts in water from dug wells in rainy season.

\begin{tabular}{|c|c|c|c|c|c|c|}
\hline A & \multirow[t]{2}{*}{ B } & $\mathrm{C}$ & $\mathrm{F}$ & $\mathrm{E}$ & \multicolumn{2}{|r|}{ G } \\
\hline I & & $\mathrm{L}$ & $\mathrm{M}$ & $P$ & $\mathrm{~N}$ & \\
\hline \multirow[t]{2}{*}{$\mathrm{R}$} & \multirow[t]{2}{*}{1} & 5 & 5 & 3 & 1 & 110,0000 \\
\hline & & 5 & 5 & 5 & 5 & \\
\hline \multirow[t]{2}{*}{$/ 1$} & \multirow[t]{2}{*}{2} & 5 & 2 & 0 & 0 & 49 \\
\hline & & 5 & 5 & 5 & 5 & \\
\hline \multirow[t]{2}{*}{ // } & \multirow[t]{2}{*}{3} & 5 & 4 & 2 & 0 & 220 \\
\hline & & 5 & 5 & 5 & 5 & \\
\hline \multirow[t]{2}{*}{ // } & \multirow[t]{2}{*}{4} & 5 & 5 & 3 & 1 & 110,0000 \\
\hline & & 5 & 5 & 5 & 5 & \\
\hline \multirow[t]{2}{*}{$/ /$} & \multirow[t]{2}{*}{5} & 5 & 5 & 4 & 4 & 350,0000 \\
\hline & & 5 & 5 & 5 & 5 & \\
\hline \multirow[t]{2}{*}{$/ /$} & \multirow[t]{2}{*}{6} & 4 & 4 & 3 & 1 & 33,00000 \\
\hline & & 5 & 5 & 5 & 5 & \\
\hline \multirow[t]{2}{*}{$1 /$} & \multirow[t]{2}{*}{7} & 5 & 2 & 2 & 1 & 12,0000 \\
\hline & & 5 & 5 & 5 & 5 & \\
\hline \multirow[t]{2}{*}{ // } & \multirow[t]{2}{*}{8} & 5 & 5 & 2 & 1 & 70,0000 \\
\hline & & 5 & 5 & 5 & 5 & T \\
\hline \multirow[t]{2}{*}{ /1 } & \multirow[t]{2}{*}{9} & 5 & 3 & 3 & 0 & 17 \\
\hline & & 5 & 5 & 5 & 5 & \\
\hline \multirow[t]{2}{*}{ // } & \multirow[t]{2}{*}{10} & 5 & 5 & 4 & 2 & 220,0000 \\
\hline & & 5 & 5 & 5 & 5 & \\
\hline \multirow[t]{2}{*}{ /I } & \multirow[t]{2}{*}{11} & 4 & 3 & 3 & 2 & 20,0000 \\
\hline & & 5 & 5 & 5 & 5 & \\
\hline \multirow[t]{2}{*}{ // } & \multirow[t]{2}{*}{12} & 5 & 4 & 3 & 3 & 45,0000 \\
\hline & & 5 & 5 & 5 & 5 & \\
\hline$/ /$ & 13 & 0 & 0 & 0 & 0 & 0 \\
\hline \multirow[t]{2}{*}{$/ 1$} & \multirow[t]{2}{*}{14} & 5 & 2 & 3 & 0 & 120 \\
\hline & & 5 & 5 & 5 & 5 & \\
\hline$/ /$ & 15 & 0 & 0 & 0 & 0 & 0 \\
\hline
\end{tabular}

Where: A: volume of water added to medium., B: serial No., C: $10 \mathrm{mLx} 5 \times 5 \mathrm{~mL}$., F: $1 \mathrm{~mL} \times 5 \times 5 \mathrm{~mL}$., E: $0.1 \mathrm{~mL} \times 5 \times 5 \mathrm{~mL}$., G: $0.00001 \mathrm{mLx} 5$., H: MPN/100mL., I: source of water ezamined., L: No. of coliforms+ve in $10 \mathrm{~mL}$ double strength medium., M: No. of coliforms+ve in $5 \mathrm{~mL}$ single strength medium. P: No. of coliforms +ve in $5 \mathrm{~mL}$ single strength medium. No. of coliforms + ve in $5 \mathrm{~mL}$ strength medium. R: dug well ( open ).

MPN: most probable number.
Table 2: Results of total presumptive E. faecalis counts in water from dug wells in rainy season.

\begin{tabular}{|c|c|c|c|c|c|c|}
\hline A & \multirow[t]{2}{*}{ B } & $\mathrm{C}$ & $\mathrm{F}$ & $\mathrm{E}$ & \multicolumn{2}{|r|}{$\mathrm{G}$} \\
\hline I & & $\mathrm{L}$ & $\mathrm{M}$ & $\mathrm{P}$ & $\mathrm{N}$ & $\mathrm{H}$ \\
\hline $\mathrm{R}$ & 1 & 5 & 5 & 4 & 4 & 350,0000 \\
\hline & & 5 & 5 & 5 & 5 & \\
\hline$/ /$ & 2 & 5 & 4 & 3 & 2 & 39,0000 \\
\hline & & 5 & 5 & 5 & 5 & \\
\hline // & 3 & 5 & 5 & 2 & 3 & 120,0000 \\
\hline & & 5 & 5 & 5 & 5 & \\
\hline // & 4 & 0 & 0 & 0 & 0 & 0 \\
\hline // & 5 & 5 & 5 & 5 & 3 & 920,0000 \\
\hline & & 5 & 5 & 5 & 5 & \\
\hline // & 6 & 5 & 5 & 5 & 4 & 160,00000 \\
\hline & & 5 & 5 & 5 & 5 & \\
\hline // & 7 & 5 & 5 & 4 & 2 & 220,0000 \\
\hline & & 5 & 5 & 5 & 5 & \\
\hline // & 8 & 5 & 5 & 4 & 3 & 280,0000 \\
\hline & & 5 & 5 & 5 & 5 & \\
\hline // & 9 & 5 & 5 & 5 & 4 & 1600,0000 \\
\hline & & 5 & 5 & 5 & 5 & \\
\hline // & 10 & 5 & 5 & 4 & 4 & 350,0000 \\
\hline 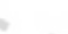 & & 5 & 5 & 5 & 5 & \\
\hline $1 /$ & 11 & 5 & 5 & 3 & 2 & 140,0000 \\
\hline & $1+1$ & 5 & 5 & 5 & 5 & \\
\hline $1 /$ & 12 & 5 & 5 & 4 & 4 & 540,0000 \\
\hline & & 5 & 5 & 5 & 5 & \\
\hline // & 13 & 5 & 5 & 4 & 4 & 350,0000 \\
\hline & & 5 & 5 & 5 & 5 & \\
\hline // & 14 & 5 & 5 & 5 & 2 & 5400000 \\
\hline & & 5 & 5 & 5 & 5 & \\
\hline // & 15 & 0 & 0 & 0 & 0 & 0 \\
\hline
\end{tabular}

Where: A: volume of water added to medium., B: serial No., C: $10 \mathrm{mLx} 5 \times 5 \mathrm{~mL}$., F: $1 \mathrm{mLx} 5 \times 5 \mathrm{~mL}$., E: $0.1 \mathrm{mLx} 5 \times 5 \mathrm{~mL}$., G: $0.00001 \mathrm{mLx} 5$., H: MPN/100mL., I: source of water examined., L: No. of E.faecalis+ve in $10 \mathrm{~mL}$ double strength medium., M: No. of E.faecalis +ve in $5 \mathrm{~mL}$ single strength medium. P: No. of E.faecalis +ve in $5 \mathrm{~mL}$ single strength medium. No. of E.faecalis + ve in $5 \mathrm{~mL}$ strength medium. R: dug wells ( open )

MPN: most probable number.

Table: 3 -a , shows the Independent sample T- test for MPN of Coliform and E. faecalis in dug wells.

\begin{tabular}{|c|c|c|c|c|c|}
\hline \multicolumn{7}{|c|}{ A } \\
\hline & $\mathrm{B}$ & $\mathrm{C}$ & $\mathrm{D}$ & $\mathrm{K}$ & $\mathrm{J}$ \\
\hline $\mathrm{Q}$ & $\mathrm{W}$ & 15 & $8.4 \mathrm{E} 6$ & $1.2 \mathrm{E} 6$ & $3.12 \mathrm{E} 5$ \\
\cline { 2 - 6 } & $\mathrm{U}$ & 15 & $4.7 \mathrm{E} 6$ & $5.2 \mathrm{E} 6$ & $1.3 \mathrm{E} 6$ \\
\hline
\end{tabular}

Key: A: group statistics., B: group., C: sample size., D: mean., K: standard deviation., J: standard error mean., E: power of ten., Q: MPN.

Table: $3 b$, shows the Independent sample T- test for MPN of Coliform and E. faecalis in dug wells.

\begin{tabular}{|l|c|c|c|c|c|}
\hline \multicolumn{7}{|c|}{ A } \\
\hline & $\mathrm{B}$ & $\mathrm{C}$ & $\mathrm{D}$ & $\mathrm{K}$ & J \\
\hline \multirow{2}{*}{$\mathrm{Q}$} & $\mathrm{W}$ & 15 & $8.4 \mathrm{E} 5$ & $1.2 \mathrm{E} 6$ & $3.12 \mathrm{E} 5$ \\
\cline { 2 - 6 } & $\mathrm{U}$ & 15 & $4.7 \mathrm{E} 6$ & $5.2 \mathrm{E} 6$ & $1.3 \mathrm{E} 6$ \\
\hline
\end{tabular}

Key: A: group statistics., B: group., C: sample size., D: mean., K: standard deviation., J: standard error mean., E: power of ten., Q: MPN. 


\section{International Journal of Science and Research (IJSR) \\ ISSN (Online): 2319-7064}

Index Copernicus Value (2013): 6.14 | Impact Factor (2015): 6.391

Table: 3c, shows the Independent sample T- test for MPN of Coliform and E. faecalis in dug wells.

\begin{tabular}{|c|c|c|c|c|c|c|c|c|}
\hline \multicolumn{9}{|c|}{ Independent samples test } \\
\hline & & \multirow{3}{*}{$\mathrm{F}$} & $\mathrm{J}$ & & & $\mathrm{Y}$ & & \\
\hline & & & \multirow{2}{*}{$\mathrm{S}$} & \multirow[t]{2}{*}{$\mathrm{T}$} & \multirow[t]{2}{*}{$\mathrm{L}$} & \multirow{2}{*}{$\mathrm{U}$} & \multicolumn{2}{|c|}{$\mathrm{O}$} \\
\hline & & & & & & & $\mathrm{H}$ & I \\
\hline \multirow[t]{2}{*}{ Q } & $\mathrm{W}$ & 10.329 & 0.003 & -2.803 & 28 & 0.009 & $-3.8 \mathrm{E} 6$ & 1. 4E6 \\
\hline & Z & & & -2.803 & 15.5 & 0.013 & $-3.8 \mathrm{E} 6$ & $1.40 \mathrm{E} 6$ \\
\hline
\end{tabular}

Key: Y: T- test for equality of mean., J:Levene's test for equality of variances., $\mathrm{F}$ : frequency., $\mathrm{S}$ : significant., T:Ttest., L: degree of freedom., U: sig.2-tailed., O: 95\% confidence interval of the difference., H: lower., I: upper., Q: MPN., Z: equal variances not assumed., W: equal variances assumed.

*Standard error difference for $\mathrm{W}$, equal $1.4 \times 10^{6}$, and standard error difference for $\mathrm{Z}$, equal $1.4 \times 10^{6}$.

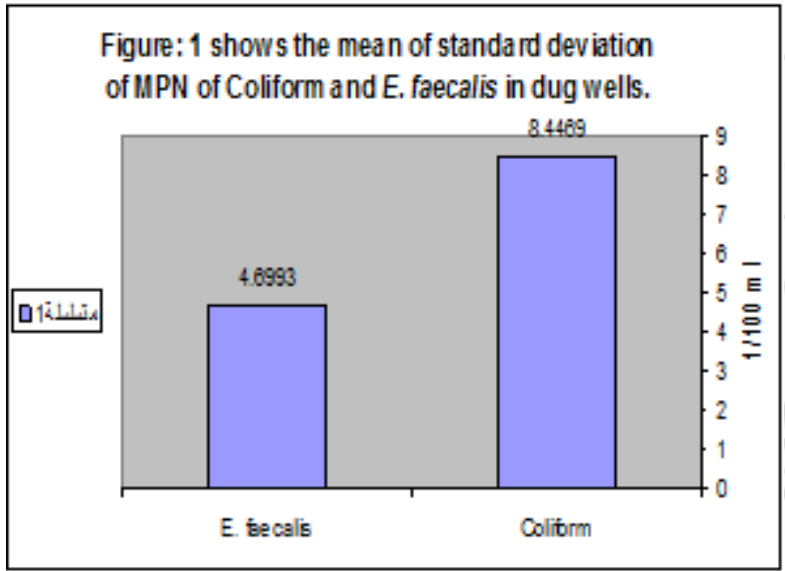

Figure 1: shows the mean of standard deviation of MPN of coliform and E.faeclis in dug wells

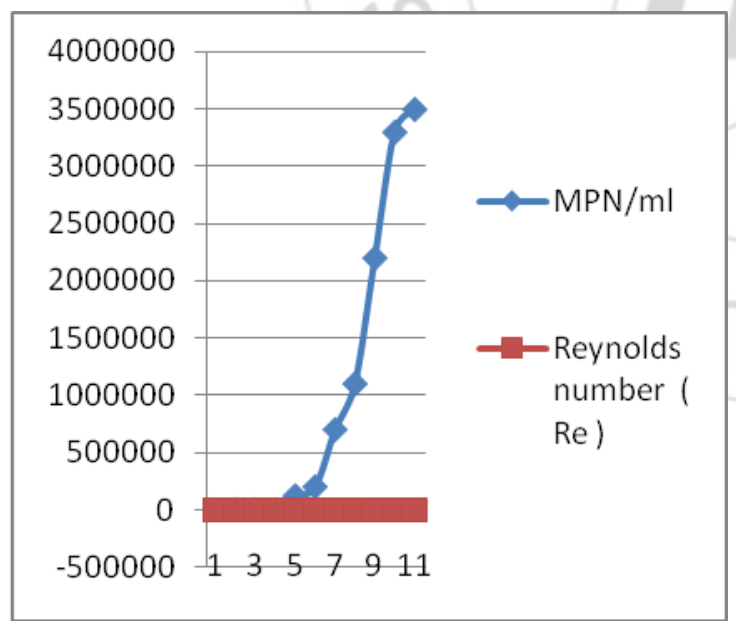

Figure 2: Reynold's number (Re )indicates the E.coliform colonies $(\mathrm{MPN} / \mathrm{ml})$ in dug wells in raining seasons.

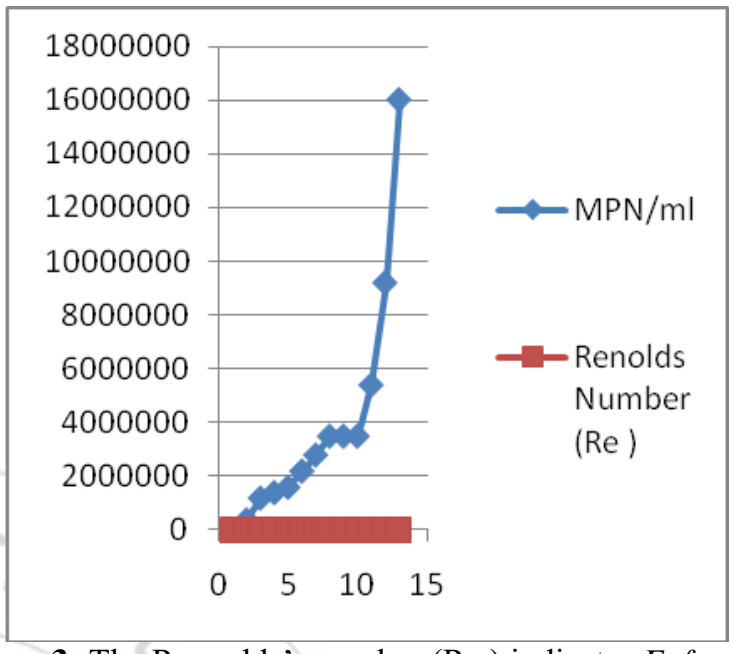

Figure 3: The Reynolds's number (Re ) indicates E. faecalis (MPN/ml) \& in dug wells in raining season.

\section{Conclusion}

It could be concluded that all the dug wells in Tolus town were contaminated with coliform and E.faecalis, and hence with dangerous pathogens. All water samples had total coliform count above the limit of WHO standard for drinking water. As reported by Davies-Colley et.al. (2001) that the consumption of drinking water contaminated with pathogenic microbes of faecal origin is a significant risk to human health in the developing world, especially in rural areas. We would like to recommend that a systematic water quality monitoring should be developed in the area to keep the water quality within WHO guidelines. Hands pumps should be installed on open wells to reduce external contamination and to enhance water quality in the study area - Also could be concluded that the nature of slow motion ( much less velocity) of the bacteria allow it to accumulate in small area according to the Reynolds's number ( Re ) which show the type of water flow, so, this indicator for contamination in dugwells of the study area. According to our knowledge its the first time that "Reynolds's number " is used for counting bacterial colonies.

\section{Acknowledgments}

We would like to express our thanks to Nyala Veterinary Research laboratory, South Darfur State for their help and technical assistance.

\section{References}

[1] Abera E. Ahmed Z. Biruktawit K. Amaare D. Solomon A. and Endalew Z. 2011 , Bacteriological analysis of drinking water sources . African journal of 
Mierobiology Research, vol 5 (18) pp 2638 - 2641 , sep. 2011.

[2] Amira A.Am Yassir ME (2011) Bacteriological quality of drinking water Nyala, south Darfur, Sudan . Environ . Monit . Assessm 175:37-43 .

[3] Battu p. R. Reddy . M.S, (2009) African journal of Biotechnology vol . 8 (20) pp 5495 - 5496. 19 October.

[4] Dahiya S, Jaur A. (1999) . Assessment of physico chemical characteristics of underground water in rural areas. Environ. J. vol. 6(4) $281-288$.

[5] Dahiya and Ka Battu ( 2009) . American Public Health Association (APHA) (1981). Standard methods for the Examination of water and waste water. $15^{\text {th }}$ ed. APHA, Washington, DC.

[6] De man (1983). MPN tables, corrected. Euro. J. Appl. Microbial. Biotechnol. 17, 301-305.

[7] Environmental Project Agency (EPA). (2000). Improved Enumeration method for the Recreation of water Quality indicator: Enterococcus and E. coli (internet search).

[8] Nada A.E. (2003). Bacteriological study of Drinking Water in Nyala Town for indication of pollution. A thesis of MSc. U. of El Neelain

[9] Ryan K. j., Ray C.G. (2004). Sherrie's medical microbiology. $4^{\text {th }}$ ed. Mc Graw Hill.

[10] WHO, (2008) Guidelines for drinking - water quality , Third Edition, Nolumet, 2008 , Geneva , pp $2-7$..

[11] World Health Organization (WHO) (1988). Guide lines for drinking water quality. Health criteria and other supporting information. Mac. Millan ceuterick, Belgium. 16/2.

[12] World Health Organization (WHO) (1999). The Epidemiology and an etiology of diarrhea diseases. WHO, control of diarrhea disease.

[13] Reynolds. ( 1883 ), “ An experimental investigation of the Circumstance which Determine whether the motion of water shall be direct or sinuous ", Philosophical Transaction of the Royal Society of London,174, 935982. 